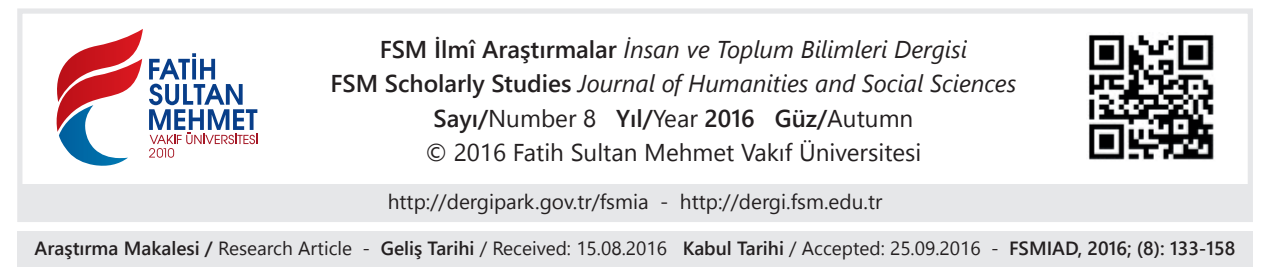

\title{
19. Yüzyıl Doğu Akdeniz Donanma Mücadelesinde Öne Çıkan Devletler ve Faktörler
}

Fatih Erbaş*

\section{$\ddot{O} \mathbf{z}$}

Doğu Akdeniz 19'uncu yüzyllda özellikle dört devletin (İngiltere, Fransa, Rusya ve Osmanlı Devleti) mücadelelerine sahne olmuştur. Bu mücadeleler zincirinde mezkûr devletler değişen formüllerde ittifaklar oluşturmuşlardır. Bu mücadeleler ve devletler beş parametre temelinde değerlendirilmiş ve mukayese edilmişlerdir. Bu parametreler jeostrateji, teknoloji, insan gücü, diplomasi, hukuk ve siyaset ile ekonomi olarak tespit edilmiştir.

Anahtar Kelimeler: Doğu Akdeniz, donanma, teknoloji, jeostrateji, deniz hukuku, ekonomi, insan gücü.

\section{The Factors and the States that Come Forward on the Naval Struggle of the Eastern Mediterranean in the $19^{\text {th }}$ Century}

\section{Abstract}

The Eastern Mediterranean became the conflict scene of the four states (Ottoman Empire, British Empire, France and Russia). The struggle and those four states have been examined and compared on the basis of the five parameters. These parameters are geostrategy, technology, human power, politics-diplomacy and economy.

Keywords: Eastern Mediterranean, navy, technology, geostrategy, maritime law, economy, man power.

* Uluslararası Güvenlik Stratejileri Doktoru, Kubbealtı Akademisi Kültür ve Sanat Vakfı Genel Sekreteri, İstanbul/Türkiye, fatiherbas@gmail.com 


\section{Giriş}

Dünyada uluslararası siyasette belirleyici olmak isteyen bir devletin, dünya ticaretinin \%80'inden fazla bir bölümünün denizler aracılığı ile yapıldığının bilinci ile denize ve denizciliğe ve dolayısıyla hem sivil, hem de askerî bahriyeye önem vermesi gerektiği değerlendirilmektedir. Bu mantıktan hareketle 19'uncu yüzyılda dünya güç mücadelesinin yaşandığı önemli düğüm noktalarını barınd1ran Doğu Akdeniz'deki deniz mücadelesi ve deniz gücünün dünya güç mücadelesine etkileri üzerinde durulmuştur. Bu çerçevede; Fransız, Rus, İngiliz ve Osmanlı deniz kuvvetleri ve denizcilik politikaları ve deniz mücadeleleri ele alınmış ve özellikle İngiliz ve Osmanlı donanmaları merkeze alınmak sûreti ile dönem ve bölge incelenmeye çalışılmıştır.

19'uncu yüzyıl genelinde Akdeniz'e ve hassaten Doğu Akdeniz'e göz atıld1ğında mücadelenin yoğunlaştığı ve güç dengesinin sık sık yer değiştirdiği görülmektedir. Bu dönemde Doğu Akdeniz güç mücadelesinin temel aktörleri Osmanlı Devleti, İngiltere, Rusya ve Fransa'dır. Bu mücadelede ön plana çıkan ise bu devletlerin deniz gücü, yani donanmalarıdır. Misır üzerinde Fransa-İngiltere-Osmanlı mücadelesi, Yedi Adalar Cumhuriyetinin kurulması, Osmanlı Devleti ile İngiltere arasında Kale-i Sultaniye anlaşması ile sonuçlanan hadiseler, Mora İsyân1, Kırım Harbi, Girit İsyân1, Osmanl1-Rus Harbi ve Osmanl1-Yunan Harbi hep bu yüzyılda donanmaların önemli roller üstlendiği hadiseleridir.

Akdeniz yüzyıllar boyu dünyayı yönlendirmiş, büyük medeniyetlere ev sahipliği yapmış, Akdeniz'den doğan kültür tüm dünyayı etkilemiştir. ${ }^{1}$ Bu çerçevede Akdeniz'e dair Fernand Braudel, David Samual Abulafia ve Adnan Husain ile Katherine Elizabeth Fleming'in eserleri bölgeyi ve dönemlerini, meselelerin sebeplerini anlamak adına önem arz etmektedir. Fernand Braudel "Akdeniz" isimli eserinde Akdeniz kültürü, tarihi, sosyolojik yapısı, iklimi ve bölgedeki mücadeleleri ele almaktadır. Braudel Akdeniz'in jeostratejik özelliklerini ortaya koymaktadır. Braudel'in takipçisi olarak ifade edilebilecek olan İngiliz tarihçi David Samuel Harvard Abulafia (1949-) da "Büyük Deniz - The Great Sea"3 isimli eserinde, M.Ö. 2200'den başlayarak bugüne kadar Akdeniz’i beş tarihî safhaya ayırmıştır. Braudel'in coğrafya üzerinden ele aldığg Akdeniz'i tarih perspektifinden bir değerlendirmeye tâbi tutmuştur. Kitapta, fertten topluma Akdeniz insanının tarihi anlatılmaktadır. Yazarın bakışı deniz gücünün alt yapısını oluşturan insan ve toplumu ele alması açısından önemlidir. Gücü kullanmada en önemli etkenlerden biri de dindir. Bu yönü ile bakılınca Akdeniz'in inanç tarihini bilmek bölgenin geçmişi ve geleceği açısından büyük önem arz etmektedir. Adnan Husain ile

1 Adnan Husain ve K.E. Fleming, A Faitful Sea, Oneworld Publications, Oxford, 2007, s.3.

2 Fernand Braudel, The Mediterranean, The University of California Press, Los Angeles, 1995.

3 David Abulafia, The Great Sea, Oxford University Press Inc., 2011. 
Katherine Elizabeth Fleming'in kitapları olan "İnanç Denizi - A Faitful Sea" adlı eser Akdeniz'e inanç ekseninden bakmaktadır.

18. yüzyıldan itibaren ve özellikle 19. yüzyılda Akdeniz daha çok bölge dış1 ülkelerin etkisine girmiştir. Bu meyanda başta Osmanlı ve İngiltere olmak üzere, Fransa ve Rusya Akdeniz'de hâkimiyet mücadelesi vermişlerdir. Bu devletler Akdeniz'de varlıklarını daha çok deniz güçleri ile ortaya koymuşlardır. Adı zikredilen devletlerin önemli özelliği, Amerika Birleşik Devletlerinin de iştirakiyle 20 ’nci yüzyılın güç merkezlerini oluşturmalarıdır.

\section{Doğu Akdeniz Mücadelesinde Dört Donanma}

Bat1 17. ve 18. yüzyılda yeni dünyalar peşinde idi. Devletlerin açılımı da buna uygundu. Büyük donanmalarla birçok ülke dünyaya açılmıştı. 19. yüzyılın ortalarına gelindiğinde dünyanın dikkati denizci ve dünya ölçeğinde bir bakış açısından kıtasal çerçeveye döndüğü tespiti yapılmıştır. ${ }^{4} 1815$ Viyana Kongresi'nden 1870'lere kadar geçen dönem yeni devletlerin kurulduğu, milliyetçiliğin etkin olduğu, içlerinde Almanya ve İtalya'nın da bulunduğu birçok devletin milli birliğini sağladığı bir dönem olmuştur. Bu dönem denizlere açılma değil, milliyetçiliğin öncelik kazandığı bir dönem olmuştur. Aynı dönemde Osmanlı Devleti hem toprak kayıpları yaşamış hem de yeniden yapılanma gayreti içinde olmuştur. Osmanlı Devleti için de denizci açılımlar öncelik listesinde yer almıyordu. ${ }^{5}$

18. yüzy1l "Yedi Yı1 Savaşları" ve ardından yaşanan Fransız Devrimi ile sona ermiş ve yeni yüzyıl, Avrupa'da yeni bir lider, Napoleon Bonaparte ile başlamıştır. Napoleon'un iktidarının kıta Avrupası'nın menfaatlerine olumsuz etkisi olmuştur. Napolyon'un uyguladığı kıta ablukası Avrupa'ya müteveccih ticareti aksatmıştır. Daha doğrusu ticaretin gelişimini yavaşlatmıştır. ${ }^{6}$

Yüzyılın yapı taşı diyebileceğimiz platform 1815 Viyana Kongresi'dir. Kongre, Avrupa'da dengeyi muhafaza etme gayreti ile kaleme alınmış bir belge ile sonuçlanmıştır. Kongre sonrası oluşan güçler dengesi Avrupa'yı ciddi bir savaş olmadan Birinci Dünya Savaşı'na kadar getirmiştir. Viyana Kongresi yüzyıllardır savaşan Avrupalıların aslında bu savaşlar süresince oluşturdukları değerler sistemini esas almış ve düzeni buna ona kurmuş önemli bir belgedir. ${ }^{7}$

Bu barış ve huzur ortamının Avrupa'da gelişmeyi tetikleyeceği düşünülmüş ancak sonuç öyle olmamıştır. Yüzyıl Fransa'nın gittikçe küçüldüğü, İngiltere'nin

4 Richard Harding, Seapower and Naval Warfare 1650-1830, Taylor \& Francis e-Library, 2001, s.2.

5 Fahir Armaoğlu, 20. Yüzyıl Siyasi Tarihi, Türkiye İş Bankası Kültür Yayınları, 6. Bask1, Ankara, 1989, s.13.

6 Rıfat Uçarol, Siyasi Tarih, Der Yayınları, İstanbul, 2013, s.57.

7 Verda Yiğit, "1648 Vestefalya Barışından 1815 Viyana Kongresine Kadar ki Dönemde Uluslararası Sistemin Dönüşümü”, (Yayımlanmamış Yüksek Lisans Tezi), İstanbu1, 2008, s.68. 
etkisini artırdığı, Avrupa'da yeni devletlerin ve yeni birliklerin gerçekleştiği bir süreç olmuştur. Osmanlı Devleti için ise bölünmeye, parçalanmaya ve küçülmeye giden yol şeklinde tezâhür etmiştir. Viyana Kongresi ile oluşan dünya sisteminin ihtiyacı olan sükûn ve emniyeti sağlayan unsurlardan biri İngiliz donanması olmuştur. Tarihte eğer bir dönem "Pax Britannica" olarak adlandırılıyorsa bunun en önemli etkeninin İngiliz donanması olduğu tartışılmaz bir gerçektir. Özellikle Trafalgar'dan sonra İngiliz donanmasının baskın rolü onay görmüştür. ${ }^{8}$

19. yüzy1lın denizlerin sahibi İngiltere'nin denizci geçmişinin tahmin edildiğinin aksine başlangıçta bilinçli ve ayrıntılı planlara sahip bir durumda olmadığı artık sık sık dile getirilmektedir. ${ }^{9}$ İngiltere'nin harp bahriyesi oluşturması ve bahriyesini geliştirmesinin temel sebebinin sadece ülke savunmasını sağlamak, yani beka olduğu belirtilmektedir. Çünkü ortada Fransa ve İspanya gibi denizlerde üstün devletler bulunmaktadır. Başlangıçta İngiltere için büyük idealler değil, sadece ülke müdafaasının önemli olarak görüldügü anlatılmaya çalışılmaktadır.

Napoleon Savaşları'nın ardından 1815'te imzalanan Viyana Antlaşması sonrası Fransa'nın donanması imha edilmiş, sonra da eski haline dönememiştir. Fransa'nın bundan sonraki Akdeniz politikası hasımlarının hasımlarını desteklemek şeklinde tezahür etmiş ve bu çerçevede Mısır'da Osmanlı'ya isyan eden Mehmed Ali Paşa Fransa tarafindan desteklenmiştir. Daha önce de arz edildiği üzere İngiltere açısından Mısır'da güçlü yeni bir devlet yerine kontrol edilebilir, kendisine muhtaç ve bağımsız Osmanlı Devleti tercih sebebiydi. ${ }^{10}$ İngiltere'nin endişesi; Mehmed Ali Paşa'nın Mısır'da başarılı olması durumunda Mısırla sınırlı kalmaması idi. Mehmed Ali Paşa kolaylıkla Suriye, Kıbrıs ve bölgedeki diğer vilayetleri ele geçirebilirdi. Ondan sonra Kuzey Afrika'ya uzanabilir ve Fransa ile bir ittifak kurabilirdi. İngiltere için bir kâbus senaryosu olan bu durumu dengelemek için İngiltere sadece Osmanlı ile işbirliğini yeterli görmedi ve Fransa'ya düşmanca duygular besleyen Rus Çarı Nikola başta olmak üzere, Prusya ve Avusturya'nın da dâhil olduğu bir ittifak oluşturdu. Aynı dönemde Mehmet Ali Paşa isyanına karşı yalnız kalan Osman11 İngiltere'den yardım talebinde bulundu. Dünyanın farklı yerlerindeki taahhütleri ve stratejik durumun yeterince iyi değerlendirilmemesi nedenleri ile İngiltere Osmanlı Devletine yardım konusunda yetersiz kaldı. Bu durumda İngiltere ile ortaklık içinde bulunan Rusya şartları değerlendirerek Osmanlı'yı ittifaka zorladı. Bu ittifak Rusya'ya ayrıcalıklar tanıyordu. Bu dönemdeki İngiltere'nin Osmanlı Devleti'ne yardımda gecikmesi bazı İngiliz tarihçiler tarafından da tenkit edilmektedir. ${ }^{11}$

8 James Kraska, Maritime Power and the Law of the Sea, Oxford University Press, Inc., 2011, s.58.

9 Geoffrey Till, Development of British Naval Thinking, Routledge, İngiltere, 2006, s.22

10 Ali Akyıldız, Zekeriya Kurşun, Osmanlı Arap Coğrafyası ve Avrupa Emperyalizmi, Türkiye İş Bankası Kültür Yayınları, İstanbul, 2014, s.7.

11 John B. Hattendorf, Naval Policy Strategy in the Mediterranean, Frank Cass \& Co. Ltd, Oregon, 2000, s.39-40. 
İngiltere ile Rusya arasındaki ilişkiler 19. yüzyılın ilk yarısında, iki ülke arasında artan rekâbet nedeniyle bozulmuştur. İngiltere Rusya'nın Akdeniz'deki varlığını kendi menfaatlerinin aleyhine olarak değerlendirmiştir. Özellikle Rusya'nın Fransa ve İspanya ile muhtemel işbirliğinin kendi menfaatlerini derinden sarsacağının farkındaydı. Bu nedenle Karadeniz' in bir süre daha Osmanlı dışındaki güçlere kapalı olması ve Boğazların geçişlere açık olmaması İngiltere için avantajlı bir durumdu. ${ }^{12}$ İngiltere 19. yüzyılın ilk başında Akdeniz'de temel olarak Fransa ile mücadele etmiştir. Fransa 18. yüzyılda Amerika'da ve dünyanın başka bölgelerinde İngiltere'ye karşı yaşadığı mağlubiyetleri kompanse etmek maksadıyla Mısır başta olmak üzere 19. yüzyılda İngiltere'ye karşı mücadele etmiş ancak bunda başarılı olamamıştır. 19. yüzyıl İngiltere açısından Fransa, Rusya, Almanya ve İtalya’ya karşı üstünlügünü muhâfaza ettiği bir yüzyıl olmuştur. Ancak şu da bir gerçektir ki, Osmanlı İmparatorluğu küçüldükçe İngiltere'nin diğer devletler karşısındaki pozisyonu da İngiltere aleyhine değişmeye başlamıştır. ${ }^{13}$

Ancak 18. yüzy1ldan itibaren ve özellikle 19. yüzyılda Akdeniz daha çok bölge dişı ülkelerin etkisine girmiştir. ${ }^{14} \mathrm{Bu}$ meyanda başta İngiltere olmak üzere, Amerika Birleşik Devletleri, Fransa (Akdeniz Devleti olmakla birlikte Atlantik'e açık yönü ile diğer Akdeniz ülkelerinden farklılık arz eder) ve Rusya Akdeniz'de hâkimiyet mücadelesi vermişlerdir. Bu devletler Akdeniz'de varlıklarını daha çok deniz güçleri ile ortaya koymuşlardır. Adı zikredilen devletlerin önemli özelliği, 20’nci yüzyılın güç merkezlerini oluşturmalarıdır.

Teknolojideki gelişmeler, Süveyş kanalının açılması, ticaretin artan hacmi, devletlerarası rekabet, Osmanlı'nın parçalanma sürecine girmesi ve benzeri nedenler Akdeniz'i 19. yüzyılda harekât alanı haline getirmiştir. ${ }^{15}$ 19. yüzyıl Akdeniz'de büyük rekâbete sahne olmuşsa da, meseleye savaş açısından bakılınca 1815 Viyana dengesinden Birinci Dünya Savaşına kadar olan süre zarfında Akdeniz' de büyük deniz savaşı yaşanmamıştır. Bu dönemden hatırlanacak en önemli olay Osmanlı donanmasının, aslında tarihte o zamana kadar pek de bir araya gelmeyen İngiliz, Rus ve Fransız ortak donanması tarafından Navarin'de yakılmasıdır. Nitekim 1827'de gerçekleşen bu hadiseyi takiben bağımsız Yunanistan ortaya çıkmıştır. Bu yüzyıl donanmaların, özellikle "Doğu Sorunu” çerçevesinde diplomatik alanda kullanıldığı bir dönem olmuştur.

12 Virginia Aksan, Osmanlı Harpleri, Türkiye İş Bankası Kültür Yayınları, 2.Baskı, İstanbul, 2011, s.509.

13 John B.Hattendorf, a.g.e., s.271-273

14 Adnan A. Husain and K.E.Fleming, a.g.e., s.3.

15 Fahir Armaoğlu, a.g.e., s.52. 


\section{Doğu Akdeniz Mücadelesinde Osmanlı Devleti}

Osmanlı Devleti, 19. yüzyıl boyunca dış politikada ağırlığını bir devletten bir devlete kaydırarak denge politikası izlemiş, muhasımları arasındaki görüşs/prensip ayrılıkları ve çıkar çatışmalarından yararlanarak kendine hayat alanı bulabilmiştir. Askerî ve ekonomik zaafiyet alanlarını diplomatik gücündeki gelişmeler ile telâfî ederek hayâtiyetini devam ettirmiştir.

Osmanlı Devleti'nin bahriyesindeki zihniyet değişikliği gayretlerinden biri hamlelerinden biri 11 Temmuz 1792/1206(Hicri) tarihli Bahriye Nizamnâmesidir. Buna göre gemiler kalyon, firkateyn, şehdiye diye cinslerine göre üç grup üzerinde tertip edilmişlerdir. Gemilerin temizliği ve kayıtların usûlüne göre tutulması, suçlar ve cezaları, liman reisliği ve görevleri ${ }^{16}$ üzerinde durulan diğer hususlardir. ${ }^{17}$

Yine aynı dönemde çıkarılan 1804/1218 tarihli Bahriye Kânunnâmesi ile kaptan paşa ve Bahriye nâzırının yetkileri, donanmada vazifeli bulunan ast ve üst rütbeli subayların görevleri ve bundan böyle alacakları maaş ve tâyinatları ayrı ayrı kurallara bağlanmak istenmiştir. ${ }^{18}$ 1804/1218 Kânunnâmesine 1805/1219 ve 1806/1220 senelerinde bir takım ilaveler yapılarak kapsam genişletilmiştir. ${ }^{19}$

Islahat hareketinden donanma da payını almıştır. 1845/1261'de Meclis' in açılmasıyla bahriye askerinin temini bir düzene bağlanmış, bunun için "Asâkir-i Bahriye Yoklama Odası" açılmıştır. Tersâne gelir-giderini kontrol altına alacak hamleler yapıldı. 1804/1218'de yürürlüğe giren Bahriye Kânunnâmesi 1849/1266'da yenilendi. Bu kanunnâme ile protokol hususları, görevler, tersânedeki yöntemler, askerin durumu, yetki ve sorumluluklar, askere alma usulleri elden geçirildi.

Bütün bu düzenlemelerin hepsi iyi niyetli gayretler olmakla birlikte, sonuçları itibarı ile arzu edilen başarı yakalanamamıştır. Bunun sebepleri arasında; düzenlemeleri başlatanların görevde kalmamaları, devlet yönetiminde istikrarsızlık ve düzensizlik, mâlî kifayetsizlik, personel kifayetsizliği, stratejik öngörüsüzlük sayılabilir. Mesela 19. Yüzyılın başında bahriye için biçilen misyonun sahilleri korumaktan ibaret olarak belirlenmesi denizlerde mücadeleyi kaybetmeyi kabullenmek anlamina gelmektedir.

Sultan Abdülaziz' in gayretleri ile Osmanlı donanması 19'uncu yüzyılın son çeyreğine 20 zırhlı, 7 korvet ve 43 nakliye gemisi ${ }^{20}$ ile İngiltere ve Fransa'nın

16 Ali İhsan Gencer, Bahriyede Yapılan Islahat Hareketleri ve Bahriye Nezaretinin Kuruluşu, Türk Tarih Kurumu Yayınları, Ankara, 2001s. 36-38.

17 Süleyman Nutki, Osmanlı Deniz Savaşları, Deniz Basımevi Müdürlüğü, İstanbul, 1993, s. 123.

18 Ali İhsan Gencer, a.g.e. s.67.

19 A.g.e., s. 62.

20 Nurşen Gök, "Donanma Cemiyetinin Anadolu'da Örgütlenmesi”, (Yayımlanmamış Doktora Tezi), Ankara, 2007, s.7,. 
ardından, sayısal olarak dünyanın en büyük üçüncü donanmasına sahip olarak girmiştir.

Sultan Aziz döneminde dünyanın sayılı donanmalarından biri olan Osmanlı donanması İkinci Abdülhamid döneminde de geliştirilmeye çalışılmıştır. ${ }^{21} \mathrm{Bu}$ dönemde Tersâne başta olmak üzere dişa bağımlılık azaltılmaya çalışılmıştır. Tersânede kruvazör, torpidobot ve firkateynler inşâ edilebilmekte, teknolojik gelişim takip edilmekteydi.

1770 Çeşme faciasından sonra Osmanlı hükûmeti donanmasını yenilemişse de bu yeni donanma tek başına Akdeniz'in gerektirdiği güce sahip değildi. Aynı zamanda, 1774 Küçük Kaynarca sonrası bir de Karadeniz sorunu çıkmıştı. Rusların Karadeniz'de görünmesi Osmanlı adına Karadeniz için de bir donanma varlığını gerekli kılıyordu. Bu da donanmadaki gemi ve personel sayısının da artması anlamina geliyordu.

Lakin devletin tüm sistemleri gibi donanmasının da elden geçtiği 19. Yüzyılın ilk yarısındaki bu dönem dış dengeler ve iç otorite açısından talihsiz bir dönem olmuştur. Dönemin sonuçlarını kategoriler halinde şu şekilde özetlemek mümkündür:

-Büyük gayretlerle yeniden inşâ edilen Osmanlı donanması lâyıkı veçhiyle kullanılamamıştır.

-Bu dönemde Yunanistan ve Sırbistan isyanları zuhur etmiştir.

-Doğu Akdeniz Fransa ve İngiltere'nin mücadelesine sahne olmuş, İngiltere bu mücadeleden galip çıkmıştır.

-Rusya İngiltere'nin desteği ve donanmasının marifeti ile Doğu Akdeniz işlerine müdahil olmuştur.

-Navarin'de Çeşme gibi Osmanlı donanması yakılmıştır.

-Mısır'da Mehmet Ali Paşa isyanında 1839'da donanma Mısır'a teslim edilmiştir.

-Ülke içinde isyan ve ayaklanmalar yaşanmış, merkezî otorite sağlanmaya çalışılmıştır.

-Bahriyede arzu edilen gelişmeler sağlanamamış ve Ege başta olmak üzere denizler Rum korsanlara bırakılmıştır.

-Sonuç olarak, 19. Yüzyılın ilk bölümü Osmanlı deniz menfaatlerinin diğer devletler karşısında arzu edilen kadar savunulamadığı bir dönem olarak kabul edilmektedir. ${ }^{22}$

21 Necip Bolat, "II.Abdülhamid Dönemi Osmanlı Askerî Sanayii”, (Yayımlanmamış Yüksek Lisans Tezi), Samsun, 2001, s. 39-48.

22 Ali İhsan Gencer, a.g.e., s.101. 
1820'ler Ege'de isyanlarla geçmiştir. Osmanlı Devleti, büyük devletlerce desteklenen Mora yarımadası ve Adalar kaynaklı, asilerin rol aldığı isyanları bastıramımış, isyanların bastırılması için Sisam'a gönderilen donanma asi teknelerine yenilmiştir. ${ }^{23}$ Benzer şekilde Sakız Adası'nda çıkan isyan ancak Cezayir ve Mısır'dan gelen donanma desteği ile bastırılabilmiştir. Girit İsyanı da ancak Mısır'dan Mehmet Ali Paşa'nın kuvvetlerinin gelmesi ile bastırılabilmiştir.

Mehmed Ali Paşa'nın Mısır'ın imkanlarını kullanarak sağladığı iktisadi başar1 ve refah ortamı sayesinde ve bununla birlikte Fransa ile yaptığı işbirliğinin de neticesi olarak oluşturduğu ordu ve donanma bölgede etkili olmaya başlamıştır. Mehmed Ali Paşa Osmanlı Devleti'ne isyanlar ve diş tehditler konusunda donanma desteği de sağlamıştır. 1827'de Yunan isyanında da yardım ve desteğini sürdürmüş, isyanı bastırmış ancak bağımsızlığa engel olamamışlardır.

Yunanistan'ın bağımsızlığının bölgede başka etkileri de olmuştur. Bunlardan biri, Fransa'nın Yunanistan'ın bağımsızlığının 1815 dengesini bozduğu iddiasıyla Cezayir'i işgal etmek arzusudur. Cezayir, Garp Ocakları adı ile Osmanlı'ya bağlı idi. Cezayir dayısının başına buyruk faaliyetleri ve Rusya'ya karşı Osmanlı'nın 1829'da harbi kaybetmesi Fransa'yı cesaretlendirmiştir. ${ }^{24}$

93 Harbi, Osmanlı Devleti ile Rusya'nın Karadeniz'de yaşadığı bir harp olmakla birlikte etkisini Akdeniz'e de taşımıştır. Harbi vesile eden İngiltere'nin "geçici" kaydı ile Kıbrıs'ı ele geçirmesi bu harbin bir sonucudur.

1898 'de Yunanistan'ın Girit'i işgal etme cesaretinin altında yatan en önemli neden, Osmanlı Devletinin böyle bir işgale karşılık verebilecek bir donanmasının bulunmayışını bilmesi olmuştur. ${ }^{25}$ Yunanistan'ın saldırısına engel olmak için donanma sefere çıkmış ancak, Hasan Râmi Paşa'nın hâtıralarında ifâde ettiği gibi, donanmadaki disiplin ve gemilerin materyal durumu hedefe erişmeyi imkânsız kılmıştır. Bu başarısızlık donanmanın yenilenmesine katkı sağlamıştır. Devletin içinde bulunduğu borç durumu arzu edilen gelişmeyi sağlamaya engel olmuştur.

Osmanlı Devleti'nin denizcilikte gerilemesinin sebepleri şu hususlara bağlanmaktadır: Denizden yetişmeyenlerin veya denizden uzak kalanların kumanda mevkiinde olmaları, büyük deniz harplerinin verdiği yorgunluk, donanmada tadilat yapılmaması, denizci personel yetiştirilmemesi. ${ }^{26}$ Ayrıca belirtmek gereken hususların da; kürekli gemilerden kalyona geçişte gecikme, Akdeniz dünyası dı-

23 Ersan Baş, Çeşme Navarin Sinop Baskınları ve Sonuçları, Piri Reis Araştırma Merkezi Yay1n1, Deniz Basımevi, İstanbul, 2007. s.127-130.

24 Erol Karcı, “Osmanlı Kaynaklarına Göre Fransa'nın Tunus'u İşgali”, (Yayımlanmamış Yüksek Lisans Tezi), Ankara, 2007. s.11.

25 Elif Süreyya Genç, “Osmanlı İmparatorluğu’nda Yenileşme ve Buhar Makineleri”, (Yayımlanmamış Doktora Tezi), İstanbul, 2005,s.141.

26 İsmail Hakkı Uzunçarşıll, Osmanlı Tarihi, Cilt 3, Türk Tarih Kurumu Basımevi, Ankara, 1982,s.316. 
şında denizcilikte meydana gelen gelişmeleri algılayamama, devletin yeni yerler ve yenilikler keşfetmeye acil ihtiyacının olmaması da sayılabilir. Devletin zenginliğini kaybetmeye başlamasının ve donanma unsurlarının gelişen teknoloji ile birlikte maliyetinin artması da donanmanın yenilikleri takibindeki aksama sebeplerinden olduğu değerlendirilmektedir. ${ }^{27}$

Osmanlı Devleti'nin denizcilikte gerilemesi diğer alanlardaki gelişmelerinden de bağımsız ele alınacak bir husus değildir. Devlet nizamındaki bozulma, merkezden uzaklaştıkça otoritedeki azalma, yetişmiş insan gücündeki zafiyetler, ekonomideki bozulma ve diğer devletlerin okyanuslara açılma, keşifler ve sanayi devrimi ile öne geçmeleri ve benzer gelişmeler Osmanlı devleti’nin her alanına olduğu gibi bahriyesine de yansımıştır.

Öte yandan, unutulmaması gereken bir husus da; Osmanlı Devleti’nin en şaşaalı dönemlerinde donanma daha önce de arz edildiği gibi dört ana parçadan müteşekkildi; İstanbul Donanması, Adalar Donanması, Mısır Donanması ve Cezayir Donanmasi. Devletin deniz gücü, bu dört kuvvetin bir araya gelmesi ile teşkil ediliyordu. Bu güçler ihtiyaca göre biraraya geliyorlar veya gelmiyorlard1. Osmanlı Donanması, bugünkü tabirle, Akdeniz'de bazı mevsimlerde "daimi kuvvet" bulundururken oluşan donanma bu dört unsurdan teşekkül ettiriliyordu. Ancak, öte yandan, mesela Ege'nin savunmasını, Misır bölgesinin savunmasını veya Cezayir kıyılarının savunmasını ilgili kuvvetler yapıyordu.

Osmanlı devleti ve donanması güç kaybedince, yani 18. Yüzyıldan itibaren ve özellikle 19. yüzyılda, devlet otoritesinin de zayıflaması ile Cezayir bölgesi ve donanması ile Misır bölgesi ve donanması ve dolayısıyla o bölgelerin savunması Osmanlı Devleti'nin kontrolünden çıkmış oldu. Osmanlı Devleti kağıt üzerinde kendine ait olan yerlere dahi donanma gücü ayıramıyordu. Payitahtın elinde kalan donanma anavatan savunmasına ancak yetebilecek cesamette idi. Daha önce de ifade edildiği gibi çıkarılan kanunname ve nizamnamelerde de adalar ve sahillerin muhafazası öncelikli görevler olarak donanmaya verilmekte idi.

Donanmanın bahse konu ayrışması ve Payitahtın donanmasının elinde de tüm vatan savunmasını yapabilecek askeri ve ekonomik güç, siyasi irade ve sayı olmayınca devlet donanmasızlığın getirdiği sıkıntıları kah ittifaklarla aşmaya ça1ışmış, kah da kayıplar yaşamıştır. Fransa'ya karşı Mısır'da İngiliz müdahalesi, Yunan isyanında Mehmet Ali Paşa donanmasının desteği, Kırım'da İngiltere desteği bu türden örneklerdir.

Bunun yanında, donanmasızlıktan ve yetersiz donamadan kaynaklanan kayıplar ve başarısızlıkları bertaraf etmek adına; yabancı müşavirler, yeni gemi satın almalar, eğitim müesseseleri oluşturmak, kanuni düzenlemeler yapmak gibi

27 Nejat Tarakçı, Deniz Gücünün Osmanlı Tarihi Üzerindeki Etkileri, Deniz Kuvvetleri Yayınları, İstanbul, 2009, s.268. 
yöntemlere başvurulmuş ancak politika eksilliği nedeniyle arzu edilen başarıya ulaşılamamıştır.

Osmanlı Devleti 19'uncu yüzyıla iç karışıklıklar ve Mısır'a yönelik Fransız tecavüzü ve bu tecavüzün İngiltere tarafından savuşturulması ile girmiştir. Söz konusu yüzyıl Osmanlı Devleti'nin büyük kayıplar yaşadığı bir dönem olmuştur. Misır, Yunanistan, Cezayir, Sırbistan, Kıbrıs, Tunus, Karadeniz, Boğazların kontrolü, Ege'deki bir kısım adalar hep bu yüzyılda Osmanlı'nın kaybettiği topraklardır. 19'uncu yüzyıl başından sonuna kadar Osmanlı Devleti'nin savunmada kaldığı, kaybettiği, kaybetmemek için bir devlet veya devlet grubu ile işbirliğinden diğeri ile işbirliğine savrulduğu bir dönem olmuştur.

\section{Doğu Akdeniz Mücadelesinde İngiltere'nin Stratejisi}

Dünyaya denizlerden bakanlardan biri olan Sir Julian Corbett'e göre ${ }^{28}$ deniz gücü üstündür ve söz konusu olan Akdeniz ise en üstün gerçektir. Ona göre İngiltere Akdeniz'e müdâhil olmakta gecikmiştir. Yine bu anlayıştan devam ile ona göre Akdeniz'i hesaba katan İngiliz devlet adamları büyüktür, Akdeniz'i hesaplarına dâhil etmeyenler ileri görüşlü değillerdir. Sir Corbett İngiltere ile gittiği yerleri ve hassaten Akdeniz'i öylesine ilişkilendirmektedir ki, ona göre İngiltere'nin Akdeniz' de var olmaya çalışması Akdeniz'de köklü değişikliklere sebep olmuştur.

Sömürgeler çağı olarak adlandırılabilecek 18. yüzyılın sonu ve 19. yüzyı1ın ilk bölümünde İngiltere Fransa'ya karşı belirgin bir üstünlük kurmuştur. Bunun farkında olan Fransa Akdeniz'de üstün durumda bulunmak için gayret sarf etmekteydi. Bu maksatla özellikle ticareti kontrol altında tutacak şekilde Doğu Akdeniz'e, Süveyş'e hâkim olma gayretindeydi. Böylelikle 18. yüz yılın son bölümünde dünya denizlerinde İngiltere'ye karşı kaybettiği avantajı dengelemek istiyordu. İngiltere açısından da Fransa'nın Akdeniz ile sınırlı kalması İngiltere menfaatine olmakla birlikte, Fransa'nın Akdeniz ile sınırlı kalması gereken deniz varlığı Akdeniz'e hâkimiyet anlamına da gelmemeliydi. Halbûki Fransa ticaret yollarını ve Mısır'ı ele geçirmek gibi stratejik hamleler peşinde idi. Bu açıdan İngiltere için Akdeniz denge siyaseti önemli bir yer işgal ediyordu.

İngiltere açısından Doğu Akdeniz'de güçlü değil, Rusya'nın hızını kesecek, kendisine sorun çıkarmayacak bir devlet gerekli idi. Bu yönü ile Osmanlı Devleti İngiltere için tercih edilebilir bir ortak özelliği taşıyordu. İşte Fransa'nın Mısır'1 işgal hamlesi İngiltere ile Osmanlı’yı iyice birbirine yaklaştırmıştır. Osmanlı Devleti Mısır konusunda Fransa ile başa çıkamayacağından hareketle İngiltere'ye muhtaçken, İngiltere de yukarıda sayılan sebeplerle Osmanlı'ya muhtaç

28 R. C. H. Catterall, "England in the Mediterranean: A Study of the Rise and Influence of British Power within theStraits, 1603-1713 by Julian S. Corbett", Historical Review, Vol. 10, No. 1 (Oct., 1904), pp. 164-168 
durumdayd1. 19. Yüzyılın özellikle ikinci yarısında İngiltere ile Osmanlı Devleti arasındaki ilişkiler gelişmiş, İngiltere Osmanlı askerî teşkilâtının yeniden yapılanmasında etkin rol almak çerçevesinde askerî uzmanlarını Osmanlı Devletinde görevlendirmiştir. Aynı dönemde, Rusya da İngiltere'ye benzer nedenlerle Fransa'nın Doğu Akdeniz ve hassaten Misır hâkimiyetine muhalefet ediyordu. Bu durum 19'uncu yüzyılın başında Osmanlı Devleti, İngiltere ve Rusya'yı birbirine yaklaştırmıştır. İngiltere, zayıf durumda olan Osmanlı Devleti nedeni ile önce Rusya'nın, bilâhare Almanya'nın Akdeniz meselelerinde etkin bir güç olmasını engellemek maksadıyla 1878 Berlin Konferansından sonra Osmanlı hâkimiyetindeki Kıbrıs'1 ve Mısır'1 ele geçirmiştir. ${ }^{29}$ Akdeniz, sömürgeci devletlerin Afrika, Hint Okyanusu ve ötelere erişimini sağlayan kritik bölge konumunda idi. Hammadde, insan gücü ve pazar için gerekli alanlara erişim için Akdeniz geçiş bölgesi idi. Bu sebep Akdeniz'i büyük güçler için rekâbet alanı haline getirmiştir. ${ }^{30}$

Doğu Akdeniz'de İngiltere ile Fransa'nın mücadeleleri doğrudan Osmanlı Devletini ilgilendirmiştir. Bu iki devlet 19'uncu yüzyılın başlangıcında hasım, bitiminde müttefik durumundadırlar. Fransa ile İngiltere'nin Akdeniz mücadelesi önce Mısır özelinde somutlaşmış, bilâhare Avrupa güç dengesi bağlamında iki devlet müttefik olmayı seçmişler, bu ittifak her zaman dostluk sebebiyle değil bazen zorunlulukla gerçekleşmiştir. İngiltere ile Fransa arasındaki Akdeniz rekâbeti özellikle deniz alanlarının egemenliği üzerinde gerçekleşmiştir. Bu rekâbet İngiltere'nin hâkimiyetini kabul ettirmesini takiben ortaklık şekline bürünmüştür.

19. yüzy1l İngiltere'nin Doğu Akdeniz'de menfaatleri uğruna izlediği farklı politikalarla örülmüştür. Fransa'yı Mısır'dan def için Osmanlı ile birlikte hareket eden İngiltere Navarin'de Osmanlı'ya karşı ve Fransa ve Rusya ile birlikte olmuştur. Ancak Kırım Harbi'nde Rusya'nın bölgede etkisinin artacağı endişesi ile Osmanlı ile birlikte hareket etmiştir. Kavalalı Mehmet Ali Paşa'nın isyanında da Osmanlı toprak bütünlüğünden yana tavır koymuştur. Genel olarak 19'uncu yüzy11 İngiltere'nin Osmanlı politikasını özetlemek gerekirse; Osmanlı toprak bütünlüğünden yana olmakla birlikte, Osmanlı'nın zayıflamasına zemin hazırlayacak unsurları desteklemek ve bölgede üçüncü bir devletin bir güç merkezi olarak ortaya çıkmasına engel olmak şeklinde özetlenebilir. İngiltere bu politikayı ağırlıklı olarak deniz kuvvetleri vasıtası ile uygulamıştır.

19'uncu yüzyıl ittifaklar bakımından ilginç birliktelikler ve husumetlerin yaşandığ 1 bir yüzyıldır. Yüzyıla dost girenler bilahare düşman olmuş, dostluklar sık sık yer değiştirmiştir. ${ }^{31} 18$. yüzyılda ve 19 . yüzyılın ilk bölümünde Fransa

29 Mensur Akgün, "Great Powers and Straits", The Turkish Year Book, 1994, Vol.: XXIV, s.5786

30 Emine Altunay Şam, "Mısır'ın 1882'de İngilizler Tarafından İşgali ve Osmanlı Devletinin Takip Ettiği Siyaset”, (Yayımlanmamış Yüksek Lisans Tezi), Samsun, 2001.s.13.

31 John B.Hattendorf, a.g.e., s.41. 
ile büyük sorunlar yaşayan İngiltere, o dönemde Rusya ile işbirliği yapmış, bu süreçten hemen sonra Kırım söz konusu olduğunda, aslında Rusya'nın bölgesel ve küresel ölçekli mücadelenin içinde yer alma isteği ortaya çıkınca birbirlerine düşman olan Avrupalı güçler İngiltere ve Fransa işbirliğinin gerekli olduğunu görmüşler ve Rusya'ya karşı birlikte hareket ederek Rusya'nın dünya siyaset sahnesinde bir müddet daha devre dışı kalmasını sağlamışlardır. Bu çerçevede donanma üstünlügü yine bu mücadelenin belirleyici unsuru olmuştur. Ancak İngiltere'nin tutarlı ve başarılı dış politikası da en az deniz gücü kadar etkiliydi.

İngiliz donanmasının etkin bir güç olarak gelişmesinin sebepleri arasında eğitim, tersâneler ve benzeri hususlar bulunmakla birlikte donanmanın gelişmeye başladığ 1 dönemde bürokraside ve hükümette görev almış önemli ve yetkin insanların da bu gelişmede büyük rolü bulunmaktadır. Henry Palmerston bunlardan biridir. 1783'te Savaş Bakanlığına bağlı olarak kurulan Savaş Bürosundaki görevi ve bilahare 1809-1828 arası Savaş Bakanlığ1 yapmas1 ve nihayetinde $1855-58$ ve 1859-65 arasında başbakanlık yapması İngiliz donanmasının dünyanın bir numarası olmasında etkili olmuştur. ${ }^{32}$ Her milletin hayatında böylesine önemli liderler bulunmaktadır. Bu liderler sayesinde o milletler normal şartlarda daha uzun yıllarda alacakları mesafeyi daha kısa sürede alabilmektedirler. İşte Henry Palmerston da İngiliz donanmasının deniz aşırı faaliyetlerini gerçekleştirmesini ve sürdürmesini sağlayan temel bürokratik atılımları yapan ve teşkilatı oluşturan önemli bir bireydir.

İngiltere 1889 'da kabul ettiği Donanma Savunma Kanununda, aynı yüz yıl önce olduğu gibi denizlerde üstünlügü esas alan ve donanmayı aynı zamanda iki devletin deniz gücü ile baş edecek bir durumda muhâfazayı esas alıyordu. ${ }^{33}$

19 yüzyılın son çeyreğinde İngiltere için tehlike çanları çalmaya başlamıştır. Özellikle 1878 'den sonra Fransa, Rusya ve İtalya'nın "Jeune Ecole"u esas alan yeni donanma programlarını uygulamaya sokmaları ve takiben Almanya'nın da yavaş yavaş bir deniz gücü oluşturmaya başlaması, İngiltere'nin "iki donanma eşittir İngiliz donanması” anlayışını tehlikeye sokmuştur. Bunun üzerine 1889'da Donanma Savunma Kanunu hazırlanmış ve donanmanın ihtiyaçları yeniden ele alınmıştır. Bu kanun ile İngiltere son yirmi yılda izlediği politikalardan vazgeçmiş, "Jeune Ecole" uygulamalarını bırakmış, yeniden büyük donanma yapılanmasını esas almıştır. ${ }^{34}$ için Donanma bütçesi 53 milyon dolardan 76 milyon dolara yükseltilmiştir. ${ }^{35}$

32 John B.Hattendorf, Naval Policy Strategy in the Mediterranean, s.41.

33 Peter Simkins vd., The First World War, The War to End All Wars, Osprey Publishing Limited, İngiltere, 2003. s.22

34 Lawrence Sondhaus, Naval Warfare 1815-1914, Taylor \& Francis e-Library, 2001, s.161.

35 Geoffrey Wawro, Warfare and Society in Europe, 1792-1914, Taylor \& Francis e-Library, 2000, s.163. 
İngiltere 20. yüzy1lın hemen başında 1905'te dretnot dönemini başlatarak diğer devletlerin de donanma algılarının değişmesini sağlamıştır. ${ }^{36}$

İngiltere'nin dünya hakimiyetinin en önemli unsurları gemiler ise, o gemilerin yararlandığı ve devletin kurumsal gücünü gösteren deniz üsleri de bir o kadar önemlidir. 19'uncu yüzyılın son döneminde toplam İngiliz deniz üssü sayıs1 38 'dir. Bunların bölgesel dağılımı şu şekildedir:

Deniz Üslerinin bölgelere göre sayısal dağılımı ise şu şekildedir: 3 Kuzey Amerika'da, 4 Orta Amerika'da, 1 Güney Amerika'da, 2 Atlantik'te, 6 Afrika'da, 3 Uzak Asya'da, 5 Akdeniz'de, 7 Hind Denizi'nde ve 7 Okyanusya' da. ${ }^{37}$

İngiltere'nin dünyanın dört bir yanında yaklaşık sekiz donanma filosu vardı. Bunların en önemlisi anavatan savunması için oluşturulan Kanal Filosu iken ikinci önemdeki filo, ticarî menfaatlerin dügümlendiği Akdeniz filosu idi. ${ }^{38}$

İngiltere, 19'uncu yüzyılı temel rakibi sayılabilecek Fransa'ya karşı denizlerde aldığ1 ve yansımaları sömürgelerde ve ekonomik alanda da görülen galibiyetlerle karşılamıştır. Yüzyılın başlangıcı İngiltere'nin kademe kademe hegemonyasını zirveye taşıdığı dönemdir. Özellikle Napolyon Savaşlarının sona erip Viyana Kongresi'nin sonuçlarının ilan edilmesi ile İngiliz hegemonyası teyit edilmiştir. Napolyon Savaşlarından sonra İngiliz donanması kendisine en yakın rakibi Fransız donanmasından iki kat büyüktü. Bu durumda uzun süre İngiltere’ye vaki tehdit söz konusu olmamıştır. ${ }^{39} 1815^{\prime}$ 'den yüzyılın sonuna kadarki dönem İngiltere'nin denizlerdeki ve dünyanın pek çok yerindeki üstünlügünü sürdürdüğü ve sürdürme gayretini gösterdiği süreç olmuştur.

\section{Doğu Akdeniz Mücadelesinde Fransa}

Aynı zamanda bir Akdeniz devleti de olan Fransa 19. yüzyıl öncesi donanması sayesinde dünyanın birçok bölgesinde varlık göstermiş ve sömürgeler elde etmiştir. 19. yüzyıla yaklaşırken bu toprakları ve menfaatleri İngiltere’ye bırakmaya başlamıştır.

16. yüzyıldan 18. yüzyılın sonuna kadar Doğu Akdeniz'de en büyük ticarî menfaat sahibi Batı Avrupa devleti Fransa idi. Fransa, bu çerçevede Osmanlı Devleti ile de ilişkilerini iyi tutmaktaydı. Bunun karşıllğı olarak Osmanlı Devletinden bazı imtiyazlar da kazanmıştı. 18'. yüzyıla gelindiğinde dahi Avrupa ile Osmanlı Devletinin ticaretinin yarısının kontrolü Fransa'nın elindeydi. ${ }^{40} \mathrm{Bu}$ du-

36 James Lawrence, The Rise and Fall of the British Empire, St.Martin's Press, New York, 1996, s.213.

37 John Darwin, The Empire Project, Cambridge University Press, Cambridge, 2009, s.76.

38 Gregory Fremont-Barnes, The Royal Navy 1793-1815, Osprey Publishing, Oxford, 2007, s.16.

39 Lawrence Sondhaus, Navies of Modern World History, Reaktion Books, London, 2004, s.9

40 Michael Greenhalgh, "French Military Reconnaissance In The Ottoman Empire During The Eighteenth And Nineteenth Centuries As A Source For Our Knowledge Of Ancient Monuments", The Journal of Military History 66.2 (Apr 2002): 359-388 
rum güçlü diplomasi ve güçlü deniz kuvvetleri gerektiriyordu. İngiltere Akdeniz'de görünene kadar bu durum böyle sürdü.

Fransa 18. yüzy1lın sonuna doğru, ticaret hâkimiyetini devam ettiren bir devlet idi. Fransa için İspanya ve Osmanlı en iyi pazarlardı. Bundan başka olarak Osmanlı Devleti'nin Avrupa ile ticaretinin yarısına yakını Fransa tarafından gerçekleştirilmekteydi. Bu nedenle bakıldığında dahi Fransa açısından Osmanlı devletinin bölünmezliği gerekliydi. Fransa 19. yüzyıla girerken bu fikri savunuyordu. Fransa açısından Osmanlı Devleti, Rusya ve Avusturya'yı dizginleyecek bir silah olarak düşünülmeliydi. ${ }^{41}$

Deniz gücü mukayesesi açısından 19. yüzyılda ele alınması gereken en önemli iki devlet İngiltere ile Fransa'dır. Yüzyılın başında bu iki devletin donanma gücü aşağı yukarı denk vaziyette idi. Ateş gücü bakımından İngiltere'nin nisbî bir üstünlüğü söz konusu idi. Ancak İngiltere, 18. yüzyılın ikinci yarısından itibaren Fransa'ya karşı başarılarını tüm 19. yüzyıl boyunca sürdürmüş (bazen müttefik olmalarına rağmen), yüzyılın ikinci yarısında Fransa'ya karşı her alanda olduğu gibi, hem nitelik, hem nicelik bakımından deniz kuvvetleri açısından da bâriz üstünlük kurmuştur. ${ }^{42}$

18. yüzyılda dünya dengeleri açısından Fransa'nın lehine ortaya çıkan durum 19. yüzyılın başında değişmeye başlamıştır. Bunda, İngiltere'nin özellikle denizlerde olmak üzere, Fransa'ya karşı üstünlük sağlamasının etkisi olmakla birlikte birbirleri hakkındaki endişelerini dahi geri plana atmaya razı olmuş İngiltere ile Rusya'nın işbirliğinin etkisi de olmuştur. Bu işbirliği ete kemiğe bürünmüş ve 11 Nisan 1805 'te Londra'da İngiliz-Rus İttifak Antlaşması şeklinde ortaya çıkmıştır. ${ }^{43}$

Bu ittifak, denizlerde Fransa’ya karşı Trafalgar ile kurulan üstünlüğü pekiştirmek ve Fransa'nın Avrupa barış ve istikrarını bozmasını engelleyecek sınırları ve şartları oluşturmak gayesi ile yapılmıştır. Bu ittifaka Osmanlı da dâhil edilmişti. İngiltere açısından Doğu Akdeniz dengeleri dikkate alındığında Rusların katkıs1 önemli idi. Nitekim Osmanlı Devleti Fransa ile savaş sürdüğü müddetçe Rus gemilerinin Boğazlardan çıkışına izin veriyordu. ${ }^{44}$ Böylelikle Doğu Akdeniz'de Mora isyanına kadar sürecek güvenilir olmayan bir işbirliği ortamı oluşuyordu.

Ancak Napoleon mücadeleyi bırakmadı ve Batı Avrupa'daki mücadelesinde başarılı oldu. Fransa'nın başarısı Rusya'yı ona yaklaştırdı. İngiltere yalnız kalın-

41 Rifat Uçarol, Siyasi Tarih, s.63.

42 Durmuş Akalın ve Cemil Çelik, “XIX. Yüzyılda Doğu Akdeniz'de İngiliz-Fransız Rekabeti ve Osmanlı Devleti”, p. 21-45.

43 Charles Phillips and Alan Axelrod, Encyclopedia of Historical Treaties and Alliances, Second Edition, Facts On File, Inc., New York, 2006, s.166.

44 Hasan Şahin, "Doğu Sorunu Çerçevesinde Osmanlı -Fransız İlişkileri", Atatürk Üniversitesi Türkiyat Araştırmaları Enstitüsü Dergisi Sayı 40, Erzurum 2009, s. 277-315. 
ca barış yapıldı. Fransa ve İngiltere birbirlerinin menfaatlerini tanıdılar. Fransa Mısır'dan tamamen çekildi, İngiltere Fransa'nın kurduğu düzeni tanıdı. Bunu Napoleon'un kendini imparator ilân etmesi takip etti. Napoleon Akdeniz'e hâkim bir deniz gücü olmayı hedef olarak belirlemişti. Bunun için İngiltere'yi yenmesi gerektiğini biliyordu. Napoleon'un ihtiraslarından rahatsız olan İngiltere, Rusya, Avusturya ve İsviçre Fransa'ya karşı koalisyon oluşturarak savaş ilan ettiler. Napoleon her ne kadar denizlerde başarılı olamasa da karada Avusturya'yı dize getirmiş ve Temmuz 1806'da Alman Prensliklerini Fransız korumasındaki Ren Konfederasyonu altında birleştirmeyi başarmıştı. Ancak denizlerde İspanya'nın desteğine rağmen İngiltere'ye karşı başarılı olamamıştır ${ }^{45}$.

Fransa 19'uncu yüzy1la genel anlamda sömürgelerini ve egemenlik sahalarını savunma kaygısı ile girmiştir. Artık 18 'inci yüzyıl gibi rahat değildir. Her alanda İngiltere'ye karşı kaybetmektedir. Yüzyılın ilk bölümünde de Naplyon Savaşlarını kaybetmiş bir devlet olarak Viyana Kongresi'ne ulaşmıştır. Fransa 1815 'den sonra daha önce muhasımı olan İngiltere ile işbirliği mekanizmaları üreterek menfaatlerini koruma yolunu seçmiştir.

\section{Doğu Akdeniz Mücadelesinde Rusya}

Akdeniz'in tarih boyu tâlî deniz güçlerinden biri olmuş olan Rusya'nın deniz gücünü oluşturmasında ve Akdeniz'de bulunmasında en önemli rolü İngiltere oynamıştır. 18. yüzyılın son döneminde İngiltere ile Rusya'nın ilişkisini İngiltere'nin Rusya'ya denizcilik, “Akdeniz'i ve büyük devlet olmayı” öğretmesi olarak algılamak mümkündür. Bir başka bakış açısına göre de, bu durum İngiltere'nin Rusya'yı Asya'daki menfaatlerden uzak tutmasıdır. Bir başka yoruma göre ise durum İngiltere'nin Rusya'yı kullanmasından başka bir şey değildir. ${ }^{46} \mathrm{Bu}$ bakış açısına göre söz konusu dönemdeki İngiliz-Rus ilişkisinden Rusya'nın bir menfaati olmamıştır. Ancak meseleye çok boyutlu olarak bakıldığında ortaya çıkan resme göre bu ilişki sayesinde; İngiltere Osmanlı ile doğrudan mücadele etmemiş, Rusya'yı kullanmıştır. Doğu Akdeniz'de İngiliz-Rus işbirliği Fransa'nın aleyhine tezâhür etmiştir. Rusya, Asya bölgesinden uzak kalmış, denizcilik ve donanma edinme konusunda tecrübe edinmiş, Akdeniz'e uyum sağlamış ve o devirden sonra Akdeniz'in unsurlarından biri olmuştur.

Rusya'nın 18. yüzyılın son döneminde Osmanlı ile savaşları Rusya'nın deniz üssü olacak olan Sivastopol'un temellerini atmıştır. 19. yüzyıl başından itibaren Rusya'nın Osmanlı üzerindeki baskısı hissedilmeye başlandı. Baskı alanları deniz yetkileri, ticaret ve Osmanlı tebaası Ortodoks halklar olarak ortaya çıktı. Rus-

45 Mümtaz Onur Gürer, "İtalyan Krallığının Doğu Akdeniz Politikası”, (Yayımlanmamış Yüksek Lisans Tezi), İzmir, 2007, s.8,

46 Boris Kagarlitsky, Empire of the Periphery, Russia and The World System, Pluto Press, Londra 2008, s. 173 
ya Osmanlı'yı, tebaa üzerinde kontrolünü sağlayacak veya artıracak ayrıcalıklar sağlamak konusunda anlaşmalara zorluyordu..$^{47} 19$. yüzyıldaki Sırp ve Yunan isyanlarında Rusya'nın rolü büyüktür. Napoleon'un Rus ve Avusturya ordularını yenmesi Osmanlı'yı Rus isteklerini karşılamama konusunda cesaretlendirdi. Osmanlı Devleti Rusya'ya sağladığı imtiyazları kaldırdı. Fransa ile işbirliği ortamı arayan Osmanlı Devleti, Fransa işbirliğini Rusya'nın baskısından korunmak için arzu ediyordu. 1806'da Osmanl1, Rus gemilerine de Boğaz'1 kapadı. Bunun üzerine Rusya Osmanlı Devleti'ne savaş ilan etti ve Eflak-Boğdan ile Bulgaristan'ın kuzeyini ele geçirdi.

Rusya 18. yüzy1lın son döneminden itibaren Balkanlar, Doğu Akdeniz, İran ve Merkezi Asya'da Birleşik Krallık menfaatlerine tehdit teşkil eder vaziyette bir devlet olmaya başlamıştır. Avrupa'nın merkezinden Pasifik'e kadar uzanan toprakları, nüfusunun kalabalıklığ 1 , Avrupa ticaretinde artmaya başlayan etkisi ${ }^{48}$ Rusya'nın bölgedeki ağırlığını artırıyordu. Belirleyici bir güç olma yolunda ilerliyordu. Kırım Harbi bu etkiyi sınırlamıştır.

Rus-İngiliz ilişkilerinin başlangıcı İngiltere'nin Avrupa dengeleri adına Rusya'y1 desteklediği bir süreç olmuştur. İngiltere Rusya'nın hamisi, yönlendiricisi olmuştur. Bir yönü ile İngiltere Rusya'ya uluslararası ilişkileri öğreten askerîni ve diplomatını eğiten bir devlet olarak ortaya çıkmıştır. Başlangıçtaki bu durum Rusya büyüdükçe, Osmanlı üzerinde ve dolayısıyla Doğu Akdeniz üzerinde tehdit oluşturdukça önce İngiltere iç siyasetinde Rusya ile işbirliğinin faydaları tartışılmış, bilâhare Rusya'ya karşı ittifaklar oluşturulmuştur. ${ }^{49}$

Çariçe Katerina Rusya'nın Baltık'la sınırlı kalmasının dünyadaki pay yarışı için yeterli olmayacağı anlayışından hareketle Rusya'nın başka deniz ve bölgelere açılması gereğine inanan biriydi. ${ }^{50}$

Osmanlı Devleti'nin 1787'de Kırım'ı kurtarmak için giriştiği mücadele genelde deniz harpleri şeklinde tezahür etti. Rus-Türk harbinde Osmanlı tarafı birçok yerde kaybetti. Bu savaş neticesinde Rusya Karadeniz'deki varlığını güçlendirdi. Aşağı yukarı Karadeniz'in kuzeyi bu savaş sonrası tamamen Rusya'nın oldu. Rusya, 19. yüzyılın son döneminde Osmanlı'ya karşı üstünlük sağlamış ve Karadeniz'deki varlığını ispatlamış olmakla birlikte hâlâ İngiltere ve Fransa'nın ve hatta Almanya'nın gerisinde idi. ${ }^{51}$ Rusya'nın sicak denizlere inme emellerinin arka planında yer alan hususlardan en önemlilerden biri de geliştikçe kendine rakip olarak gördüğü dönemin hâkim güçleri olan Fransa ve İngiltere'nin Doğu

47 Fahir Armaoğlu, a.g.e., s.34.

48 Verda Yiğit, a.g.e., s.40.

49 Boris Kagarlitsky, a.g.e, s. 90-101

50 A.g.e. s. 162

51 Richard Harding, a.g.e., s.225-226. 
Akdeniz ve Hint Okyanusu ile oradaki ticarete hâkim rollerinden Rusya'nın da pay alma gayretidir. ${ }^{52}$ Rusya büyük devlet olmanın gerek şartlarını idrak etmiş bir devlet olarak davraniyordu.

İngiltere gibi Rusya da Osmanlı Devleti'nin yıkılmasını istemiyordu. Çar, Osmanlı devleti arzu ederse dokuz savaş gemisini Osmanlı Devleti emrine vermeye hazır olduğunu duyurdu. Osmanlı Devleti yardım teklifini prensip olarak kabul etti. Rus gemileri Büyükdere'ye geldiler. ${ }^{53}$ Ciddî manada donanması bulunmayan Rusya'nın Osmanlıya gemi yardımı teklifinde bulunması ve Osmanlı'nın bunu kabul etmek zorunda kalması durumun vahâmetini göstermesi açısından önemlidir. Bu olaydan 20 yıl sonra Kırım'da ve ondan yirmi yıl sonra 93 Harbi'nde dahi gelişmiş bir donanma sahibi olmayan Rusya'dan medet umulmuştur.

Kırım Harbinin ve Sinop Baskınının geri planında yer alan önemli hususlardan biri "Kutsal Yerler Sorunu”dur. Aslında Rusya'nın Osmanlı hâkimiyetindeki yerlerdeki Ortodoks cemaatlerin ve milletlerin koruyuculuğuna soyunmasıdır. ${ }^{54}$

Osmanlı Devleti'nin toprak bütünlügünün tehlikede olduğunu düşünen müttefikler donanmalarını bölgeye göndermeye karar verdiklerinde tarih Mart 1853'dü. İlk hareket Fransızlardan geldi. İngilizler gönderme arzusuna rağmen hareketsiz kaldılar. Kırım Harbi’nin Sinop baskını bölümü İngiltere Kraliçesi Elizabeth'in, "bir harpten çıkıldığında ne düşmanların, ne de dostların ve ne de tarafsızların Britanya'dan daha güçlü kalmaması esastır", anlayışı çerçevesinde gerçekleşmiş bir faaliyetler bütününü andırmaktadır. Neticede İngiltere'nin müttefiki Osmanlı'nın donanmasının bir bölümü imha edilmiş, İngiltere, Fransa ile birlikte Boğaz'da bulundurduğu donanmasını Karadeniz'e çıkarmak için sebep bulmuş ${ }^{55}$ ve harbin neticesinde Rusya mağlup olmuş, Osmanlı da hırpalanmıştır. ${ }^{56}$

Kırım Harbi, 1856 Paris Antlaşması ile son bulmuştur. Bu antlaşmanın en önemli maddesi, ki Karadeniz'in donanmalara kapalılı̆̆ ilkesidir, denizle ilgilidir. Karadeniz'de tersâne bulundurulmaması da yine deniz gücünün yansımaları ile ilgilidir. Tuna nehri için komisyon oluşturulması, Karadeniz'de deniz ticaretinin gündeme gelmesi hep deniz gücü ve onun yansımaları ile ilgili gayretlerdir ve bu gayretler dönemin büyük devletlerinin üstünde yoğunlaştığı ve antlaşmanın üzerinde en çok tartışıldığı konuları olmuştur. Bir yönü ile 1856 Paris Antlaşması

52 Erdoğan Keleş, “Kırım Savaşı'nda (1853-1856) Karadeniz ve Boğazlar Meselesi”, OTAM(Ankara Üniversitesi Osmanlı Tarihi Araştırma ve Uygulama Merkezi Dergisi), sayı 23 (149-194), 2008, s.151.

53 A.g.e. s.46-48.

54 Zeki Arıkan, "Kırım Savaşı ve Sinop Baskını”, Türk Denizcilik Tarihi, Deniz Basımevi Müdürlüğü, İstanbul, 2009, s.107-121.

55 Erdoğan Keleş, a.g.e., s. 171.

56 Eric J. Grove, The Royal Navy Since 1815, PALGRAVE MACMILLAN, New York, 2005, s.28-31 
deniz menfaatleri üzerine kurulmuş bir antlaşmadır. Bu antlaşma, daha doğrusu Kırım Harbi süreci Rusya'nın güneyini emniyetsiz hâle getirmiştir. Rusya'nın sıcak deniz arzuları inkıtaya uğramıştır. İngiltere açısından bu antlaşma bir büyük başarıdır. Doğu Akdeniz ve Hint yolu yeni bir muhasımdan kurtulmuştur. ${ }^{57}$

Rusya, 19'uncu yüzyıla I.Aleksandr'ın liderliği ile merhaba dedi. Yeni Çar Batı liberl anlayışına uygun adımlar attı ve İngiltere'nin liderliğindeki grupla birlikte Fransa'ya karşı olanların arasına katıld.$^{58}$ Yüzyılın ilk yarısında İngiltere'nin gayret ve desteği ile Doğu Akdeniz meselelerine müdahil olmuş ve yine İngiltere tarafından yüzyılın yarısından itibaren bölge ile irtibatı kesilen bir devlettir. Önemli hedeflerinden biri olarak Akdeniz'e inme gayretini her zaman canlı tutmuş, bölge aktörleri üzerinden mücadelenin bir parçası olmaya çalışmıştır.

58 Akdes Nimet Kurat, Rusya Tarihi, Türk Tarih Kurumu, 2.Bask1, Ankara, 1987, s.300. 


\section{Sonuç ve Değerlendirme}

Osmanlı Devleti, Doğu Akdeniz mücadelesinin geçtiği toprak ve denizin devleti olmanın jeostratejik avantajını kullanamamıştır. Eğitim, personel, yönetim, siyaset, hukuk, teknoloji ve ekonomi ile ilgili sebeplerin yanında hızlı, sürekli ve büyük toprak ve deniz alanlarının hâkimiyetinin kaybedilmesinin esas belirleyicilerden biri olduğu değerlendirilmektedir.

Teknoloji bakımından 19'uncu yüzyıl Osmanlı donanması ilişkisi ele alındığında şu sonuçlara varılmaktadır. Osmanlı Devleti ve donanması 19'uncu yüzyılda teknoloji üreten bir devlet olmamıştır. Öte yandan teknolojiye uzak bir yapı da olmamıştır. 1770 Çeşme Baskınından sonra Osmanlı Donanması teknolojiyi yakından izlemeye başlamıştır. Tersaneler elden geçirilmiş, yabancı teknik adamlar davet edilmiş, stimli gemilere Avrupa devletlerinden pek de sonra olmayan bir zamanda geçilmiş, ABD ile teknoloji transferine dayanan bir antlaşma yapılmış, daha sonra İngiltere ile ve ondan sonra Almanya ile işbirliği yapılmış, yeni teknoloji ürünü gemiler ve silahlar imal edilemese dahi gecikmeden ithal edilmiştir. Hülasa teknoloji parametresi bakımından Osmanlı Devleti belirleyici bir güç olamamıştır.

Osmanlı Devleti personel yönünden 19'uncu yüzyılı 1770'deki Çeşme faciasının personel kalitesi üzerine olumlu ve olumsuz tesirleri ile karşılamıştır. Çeşme'deki insan kaybı eğitim anlayışında yenileşmeyi tetiklemiş ancak bu eğitim hamlesi Nizam-1 Cedid ve iç isyanlarla yeniden altüst olmuştur. 19'uncu yüzyılın başındaki mücadelelerin personel kaybına etkisi derin olmuştur. Ayrıca Mora İsyanı, Navarin'deki mağlubiyet, II.Mahmud'un personel hamlesi, Misır İsyan1, donanmanın Mısır'a teslim edilmesi, eğitim yöntemlerinde yapılan değişiklikler, idari teşkilatta yapılan değişiklikler, silahlı kuvvetlerdeki disiplinsizlikler hep Osmanlı Devletinin donanmasının personel zafiyetine ve yetersizliğine zemin hazırlamış, donanma ihtiyaç duyulduğunda arz edilen sebeplerden biri veya bir kaçının etkisi ile başarısız olmuş, devletin denizlerdeki menfaatlerini koruyamamıştır.

Diplomasi, Siyaset ve Hukuk açısından 19'uncu yüzyıl Osmanlı Devleti için başarısız bir dönem olmuştur. Bir yönü ile değerlendirildiğinde; milletlerarası hukuk sayesinde siyasi ömrü uzayan Osmanlı Devleti aynı zamanda aynı hukukun parçaladığı, küçülttüğü bir devlet olarak bu yüzyılı yaşamıştır. Türk Boğazları, Mısır, Süveyş, Kıbrıs, Karadeniz, Mora, İon Denizi, Sırbistan hep bu kapsamda sayılabilecek alanlardır. Hülasa, Osmanlı donanması siyaseten güç mücadelesinde etkili olabilmiş bir güç olamamıştır.

19'uncu yüzyıl Osmanlı donanmasının ve hatta devletinin en çok sıkıntı çektiği alan siyasi istikrarsızlıktan sonra ekonomik alan idi. Devlet ekonomik olarak zor durumda idi. Borçlanmaların neticesi olarak 19'uncu yüzyılın son yirmi y1- 
lında devletin maliyesi Borçlar İdaresi tarafindan yönetiliyordu. Ondan öncesi de yüksek borçlanmadan mütevellit iflas hali idi. Bu durum yüksek maliyetli donanmaya yeterli kaynak ayrılmasına engel teşkil ediyordu. 19'uncu yüzyıl Osmanlı maliyesinin yüzyılın başından sonuna kadar devamlı kötüye gittiği bir dönem olmuştur. Mali yetersizlik donanmanın bakım onarımını ve işletilmesini de olumsuz etkiliyordu. Sonuç olarak Osmanlı donanması ekonomik yetersizliklerle boğuştuğu bu yüzyılın özellikle ikinci yarısında devletin güç mücadelesine olumlu katkı sağlayamamıştır.

İngiltere 19'uncu asırda jeostratejik açıdan Akdeniz'in batısından başlayıp doğusunda sonlanan hamlelerini 18'inci yüzyılın başında Cebel-i Tarık ile başlatmış beş adımdan oluşan hamlesini 1882 'de Mısır'da sonlandırmıştır. İngiltere, bir Akdeniz devleti olmamasına rağmen jeostratejik adımlarını en akıllıca atan ve bu adımları donanma gücü ile sağlayan ve destekleyen bir devlet olarak karşımıza çıkmaktadır. Coğrafya strateji ilişkisi an açık ve net biçimde İngiltere'nin Akdeniz politikalarında hayat bulmuştur. İngiliz donanması jeostratejik açıdan muhasımlarına ve ortaklarına nazaran büyük avantaj sağlamış ve bu avantajı deniz muharebelerinde ve antlaşmalarda kullanmıştır.

Teknolojinin donanmaların güç mücadelesinde rolü bağlamında en somut başarı hikâyesi İngiltere ve onun donanmasına aittir. Avrupa'da sanayi devriminin temelleri İngiltere'de atılmış, özgürlükçü ortamın etkisi, yönetimlerin desteği ve özellikle 19'uncu yüzyılın ilk çeyreğinde Londra'nın Avrupa finans merkezi olmasıyla İngiltere teknolojik yeniliklerin ve üretimin merkezi olmuştur. Bu durum donanma teknolojisine yansımış, İngiltere diğer devletlere teknoloji ihraç eden bir devlet haline gelmiştir. 19'uncu yüzyı1 İngiliz donanmasının teknolojik üstünlügü ile başlamış ve öyle sona ermiştir. Donanma teknolojisinin en önemli etkisi İngiltere'nin donanması ile daha uzak mesafelere, karaya daha az bağımlı gemilerle ve güçlü silahlar ve büyük hacimlerle ve daha süratli olarak güç taşımasına vesile olmuştur.

İngiliz donanmasının personel kalitesi de 19'uncu yüzyıla damga vurmuştur. 18 'inci yüzyıldan itibaren ve 19 'uncu yüzyılda da sürecek şekilde Rusya ve Yunanistan donanmalarını oluşturmuş ve geliştirmiş, Osmanlı Devleti de dahil bir çok devletin donanma personelini eğitmiş, teknik eğitimi de buna dahil etmiş bir devlettir. Eğitim hamlelerini, eğitim kitaplarını hep ilk olarak İngiltere gerçekleştirmiştir. Bu durum İngiliz donanmasının devletin gücünü etkileyen önemli bir çarpan olmasını sağlamıştır.

19'uncu yüzyıl İngiltere için siyasi ve hukuki başarılarla dolu bir yüzyıldır. Bu yüzyılda İngiliz donanmasının büyük katkısı ile çatışmalar kazanılmış, siyaset yönlendirilmiştir. Bu yüzyılda İngiltere'nin müttefiklerinin her biri sırasıyla İngiltere ve diğer ülkelerin oluşturduğu ittifakın düşmanı olmuş ve kaybetmişler, 
ancak İngiltere her zaman kazananlardan olmuştur.

19'uncu yüzyılen ekonomik açıdan en güçlü devleti İngiltere'dir. İngiltere bu gücünü daha çok sömürgelerinden kazandıkları ve deniz ticareti ile sanayi devrimi neticesi elde ettiği teknolojik üsütnlükle elde etmiştir. Bu durum bir kısır daire gibi İngiltere'ye avantaj sağlamış, İngiliz ekonomisi geliştikçe deniz ticareti gelişmiş, deniz ticareti ekonomiye katkı yapmış, deniz ticaretini korumak için donanmanın gelişmesi gerekmiş ve neticede 19'uncu yüzyılda iktisaden güçlü bir İngiltere ve bu gücün etkisi ile Doğu Akdeniz hadiseleri yönlendirilmiş, donanma etkili bir şekilde kullanılmıştır.

Jeostratejik açıdan 19'uncu yüzyıl Fransa'nın dünyanın birçok yerinde olduğu gibi Akdeniz'de de mevzi kaybettiği bir dönem olmuştur. Önce yüzyılın başında Malta ve Mısır'ı daha sonra Mora yarımadasındaki varlığını sonlandırmış ve Cezayir ve Tunus'ta kalmıştır. Dolayısıyla Doğu Akdeniz güç mücadelesinde Fransa jeostratejik açıdan dezavantajlı bir konumdadır.

Teknolojik açıdan Fransa için 19'uncu yüzyılın olumsuz olduğu ifade edilemez. Ancak İngiltere'nin aksine toprakları çatışmalara sahne olan Fransa'nın İngiltere gibi teknolojide öncü rolü olmamıştır. Fransa stim teknolojisine geçmekte gecikmemiş, donanmasında stimi etkin olarak kullanmış bir devlettir. Ancak siyaseten İngiltere'nin gölgesinde kalması her alanda Fransa'yı olumsuz etkilemiştir. Yüzyılın ikinci yarısında İngiltere'nin güçlü donanması ile başa çıkmak için küçük, süratli, sürpriz etkisi oluşturacak küçük teknelere yönelmiş ancak yine de İngiltere ile mücadelede başarılı olamamıştır.

İnsan gücü bakımından Fransa birçok alanda başarılıdır. Örgün eğitime İngiltere'den önce geçmiştir. Fransa da diğer devletlere eğitici personel göndermiş bir devlettir. Ancak genel personel kalitesi bakımından İngiltere'den geride bir devlet olup, donanmaların güç mücadelesinde bu durum ortaya çıkmıştır. Fransız ihtilali, Mısır yenilgisi ve Napolyon harpleri Fransa'nın İngiltere karşısında başarısızlığına ve geriye düşmesine zemin hazırlamıştır.

Fransa 19'uncu yüzyılda siyasi, askeri ve hukuki açıdan farklı durumlar göstermiştir. Önce askeri, siyasi ve hukuki metinler temelinde İngiltere'ye karşı kaybetmiş, bilahare İngiltere ile birlikte hareket etme siyaseti ve onunla işbirliği içinde çatışmalara girerek 19'uncu yüzyılın avantajlı devletlerinden biri olmuştur. El Ariş ve Viyana belgeleri ile kontrol altına alınan Fransa sonraki dönemde İngiltere'nin desteği ve kontrolünde Doğu Akdeniz'de etkili olan devletlerden biridir.

Fransa 19'uncu yüzyılda ekonomik olarak İngiltere kadar güçlü değilse de dünyanın geri kalan devletlerinden önde olan bir devlettir. Endüstri üretimi ve dünya ticaretinden aldığı paylar bu durumu destekler mahiyettedir. Bu ekonomik güç ile Doğu Akdeniz'de etkili olacak donanma inşa edebilmekte ve bu durumu sürdürecek kapasiteye sahiptir. İktisadi açıdan Fransa Doğu Akdeniz güç müca- 
delesinde donanmasını etkin olarak kullanabilecek bir devlettir.

Rusya, Jeostratejik olarak bölgede arzu ettiği kazanımları sağlayamamıştır. Coğrafi olarak havzada olmakla birlikte Karadeniz ve Türk Boğazları engellerinden dolayı başarılı olamamıştır. Bu engelleri faydaya çevirmek adına işbirliği hamleleri yapmış, bu çerçevede yüzyılın başında Fransa Mısır'a saldırırken Osmanlı ile ittifak oluşturmuş, daha sonra cebri olarak bölgede yer almak adına 1827'de Navarin'de Osmanlı'ya karşı tavır almış, Osmanlı Devletinin iç karışıklarından faydalanarak Rum isyanını bahane ederek Osmanlı'ya saldırmış ${ }^{59}$, ondan sonra Kavalalı Mehmet Ali Paşa'nın isyanında Osmanlı'nın durumundan yararlanmak adına hamleleri olmuş ancak en nihayetinde bölge üzerindeki Ortodoks kitle üzerindeki etkisini gösterme gayretini de gösterince İngiltere tarafından engellenmiş bir devlettir. ${ }^{60}$

Rus donanmasının insan gücünün çekirdeğini 19'uncu yüzyılın başında dahi İngilizler oluşturmaktadır. İngiltere hem personel hem de eğitim desteğinde bulunmuştur. Rusya denizci geleneğini İngiltere'den almış ve sürdürmeye çalışmış bir devlettir. Okullaşma hamlelerine devam etmiştir. İnsan gücü bakımından Rusya makul hedefleri gerçekleştirecek kapasiteye sahip bir devlet olarak mevcudiyetini sürdürmüştür.

19'uncu yüzyılda Rusya siyasi ve askeri olarak İngiltere ile birlikte hareket etmiş ve Doğu Akdeniz'de Osmanlı Devleti'ne karşı başarılar sağlamıştır. Ayrıca Rusya bölge olaylarının şekillenmesinde rol alma gayretine girmiştir. Osmanlı Devleti'nin zayıflamasından yararlanarak Ortodoks halklar ve Osmanlı toprakları üzerine hedefler gütmüştür. I.Nikola'nın saldırgan politikalarının sonucu olarak ${ }^{61}$ Kırım Harbi'nden sonra daha çok savunmada kalan ve Karadeniz'e hapsolmuş bir Rusya söz konusudur.

İktisadi bakımdan Rusya müreffeh sayılabilecek bir durumda değildir. Donanmasına büyük kaynaklar ayıramamaktadır. Sanayileşmeyi başaramamıştır. $\mathrm{Bu}$ nednele daha çok küçük gemilerden oluşan bir donanma yapılanması içine girmiştir. Sayısal olarak donanması Fransa donanmasına yakın olmakla birlikte etkinlik bakımından aynı değerde değildir.

19. yüzyılda, Doğu Akdeniz'de İngiltere nisbî donanma gücü en büyük devlettir. Bunun yanında bu gücünü en iyi kullanan devlettir de aynı zamanda. Deniz gücünü etki ve ilgi alanlarına taşıyabilmekte; bu çerçevede Akdeniz'deki siyasî ve ticarî olayları yönlendirmekte, dünya denizciliğinin teknolojik lokomotifi görevini yerine getirmekte ve böylelikle, kendinde olan güç ile doğru orantılı izlediği politikalar ve kullandığı deniz gücü sayesinde küresel hegemonik bir güç

59 A.g.e. s.324.

60 A.g.e. s.327.

61 A.g.e. s. 340 . 
olarak ortaya çıkmaktadır. O devir ele alındığında ve bundan önceki bölümlerde mukayese amaçlı kullanılan jeostrateji, teknoloji, insan gücü, diplomasi ve hukuk ile iktisadi faktörler gözönünde bulundurulduğunda rahatlıkla İngiltere'nin seviyesine uygun bir konumda ve gayrette olduğunu görmekteyiz.

Fransa ise rolü olumsuza doğru değişen ve dönüşen bir devlet durumundadır. Donanma gücü küresel ölçektedir. Ticaret, teknoloji ve insan gücü bunu desteklemektedir ancak jeostratejik açıdan mevkiler kaybetmektedir. Siyaset ve diplomaside de geri kalmaktadır. Bunun neticesinde küresel ölçekli bir devlet olarak rolü gittikçe azalan ve etki ve ilgi alanına yeterince hâkim olamayan bir devlet konumundadir.

Rusya, nisbî olarak donanma gücü daha az olmakla birlikte etki ve ilgi alanı îtibâriyle büyük hedefleri olan bir devlettir. Ancak Rusya'nın etki ve ilgi alanlarını ele geçirmesini ve muhâfazasını sağlayacak nisbî donanma gücü, teknolojik ve jeostratejik avantajları söz konusu değildir. Bu nedenle Rusya bölgesel ölçekten küresel ölçeğe geçememiştir. Nisbî donanma gücü artmıştır. Kırım Harbinde bir inkıta söz konusudur. Bu inkıta Rusya’yı Birinci Dünya Savaşına kadar devletler denkleminin dışında tutmuştur.

Osmanlı Devleti etki ve ilgi alanı îtibâriyle küresel ölçekli bir devlet olmakla birlikte, okyanuslara açılamamanın da etkisi ile küresel ölçekli bir devlet olamamıştır. Deniz gücünden 19'uncu yüzyılda, teknolojik gelişmeyi yakından takip edebildiği halde, etkin bir şekilde yararlanamamıştır. Diğer devletlerin hedefleri veya ortakları olarak varlığını sürdürmeye çalışmıştır. Buna rağmen hedefleri küreseldir ancak 19'uncu yüzyılda Osmanlı Devleti yerele yönelik bölgeselden öteye geçememiştir.

Dün anlaşılmadan yarını anlamak ve şekillendirmek mümkün değildir. Denizcilikten Türkiye'nin sağlayacağı menfaatlerin belirlenmesi ve bu çerçevede küreselleşen ve dinamik şartlarıyla sürekli değişimi kaçınılmaz kılan yeni dünyada Türk Deniz Kuvvetleri stratejilerinin nasıl olması gerektiğinin ipuçlarını da bu yaklaşımın gereği olarak târihte bulabiliriz. 


\section{Kaynakça}

\section{Kitaplar}

Abulafia, David, The Great Sea, Oxford University Press Inc., 2011

Abbott, John, The History of Napoleon Bonaparte, New York, Harper and Brothers Pub., 1883.

Akyıldız, Ali, Kurşun Zekeriya, Osmanlı Arap Coğrafyası ve Avrupa Emperyalizmi, İstanbul, Türkiye İş Bankası Kültür Yayınları, 2014.

Armaoğlu, Fahir, 20.Yüzyll Siyasi Tarihi, 6. bs., Ankara, Türkiye İş Bankası Kültür Yayınları, 1989.

Barnes, Gregory Fremont, The Royal Navy 1793-1815, Oxford, Osprey Publishing, 2007.

Black, Jeremy, European Warfare 1660-1815, Londra, University of Durham, 2003.

Braudel, Fernand, The Mediterranean, Los Angeles, The University of California Press, 1995.

Darwin, John, The Empire Project, Cambridge , Cambridge University Press, 2009.

Gencer, Ali İhsan, Bahriyede Yapılan Islahat Hareketleri ve Bahriye Nezaretinin Kuruluşu, Ankara, Türk Tarih Kurumu Yayınları, 2001.

Grovei Eric J., The Royal Navy Since 1815, New York, Palgrave Macmillan, 2005.

Harding, Richard, Seapower and Naval Warfare 1650-1830, Taylor \& Francis e-Library, 2001.

Hattendorf, John B., Naval Policy Strategy in the Mediterranean, Oregon, Frank Cass \& Co. Ltd, 2000.

Husain, Adnan A., Fleming, K.E., A Faithful Sea, Londra, Oneworld Publications, 2007.

Kagarlitsky, Boris, Empire of the Periphery, Russia and The World System, Londra, Pluto Press, 2008.

Kraska, James, Maritime Power and the Law of the Sea,Oxford University Press, Inc., 2011.

Kurat, Akdes Nimet, Rusya Tarihi, 2. bs., Ankara, Türk Tarih Kurumu, 1987.

Lawrence, James, The Rise and Fall of the British Empire, New York, St. Martin's Press, 1996. 
Nutki, Süleyman, Osmanlı Deniz Savaşları, İstanbul, Deniz Basımevi Müdürlüğü, 1993.

Philips, Charles, Axelrod, Alan, Encyclopedia of Historical Treaties and Alliances, 2nd ed., New York, Facts On File, Inc., 2006.

Sandler, Stanley, Battleships An Illustrated History of Their Impact, ABC-CLIO, Inc., 2004.

Sondhaus, Lawrence, Naval Warfare 1815-1914, the Taylor \& Francis e-Library, 2001.

, Navies of Modern World History, London, Reaktion Books, 2004.

Tarakçı, Nejat, Deniz Gücünün Osmanlı Tarihi Üzerindeki Etkileri, İstanbul, Deniz Kuvvetleri Yayınları, 2009.

Till, Geoffrey, Development of British Naval Thinking, İngiltere, Routledge, 2006.

Uçarol, Rıfat, Siyasi Tarih, İstanbul, Der Yayınları, 2013.

Uzunçarşı11, İsmail Hakkı, Osmanlı Tarihi, c. 3/2, 3. bs., Ankara, Türk Tarih Kurumu Basımevi, 1982.

Wawro, Geoffrey, Warfare and Society in Europe, 1792-1914, Taylor \& Francis e-Library, 2000.

\section{Makaleler}

Akalın, Durmuş, Çelik, Cemil, "XIX. Yüzyılda Doğu Akdeniz'de İngiliz-Fransız Rekabeti ve Osmanl1 Devleti”, Turkish Studies - International Periodical For The Languages, Literature and History of Turkish or Turkic, vol. 7/3, Summer, Ankara, 2012.

Akgün, Mensur, "Great Powers and Straits", The Turkish Year Book, vol. XXIV, 1994.

Arıkan, Zeki, “Kırım Savaşı ve Sinop Baskını”, Türk Denizcilik Tarihi, İstanbul, Deniz Basımevi Müdürlüğ̈̈, 2009.

Baş, Ersan, "Çeşme Navarin Sinop Baskınları ve Sonuçları”, Piri Reis Araştırma Merkezi Yayını, İstanbul, Deniz Basımevi, 2007.

Catterall, R. C. H., "England in the Mediterranean: A Study of the Rise and Influence of British Power within theStraits, 1603-1713 by Julian S. Corbett", Historical Review, vol. 10, no. 1, October, 1904.

Keleş, Erdoğan, "Kırım Savaşı'nda (1853-1856) Karadeniz ve Boğazlar Meselesi", OTAM (Ankara Üniversitesi Osmanlı Tarihi Araştırma ve Uygulama Merkezi Dergisi), say1 23, 2008. 


\section{Tezler}

Erbaş, Fatih, “19. Yüzyıl Doğu Akdeniz Güç Mücadelesinde Donanmaların Rolü”, (Yayımlanmamış Doktora Tezi), İstanbul, 2016.

Genç, Elif Süreyya, “Osmanlı İmparatorluğu'nda Yenileşme ve Buhar Makineleri”, (Yayımlanmamış Doktora Tezi), İstanbul, 2005.

Gök, Nurşen, "Donanma Cemiyetinin Anadolu'da Örgütlenmesi”, (Yayımlanmamış Doktora Tezi), Ankara, 2007.

Gürer, Mümtaz Onur, “İtalyan Krallığının Doğu Akdeniz Politikası”, (Yayımlanmamış Yüksek Lisans Tezi), İzmir, 2007.

Karcı, Erol, “Osmanlı Kaynaklarına Göre Fransa’nın Tunus’u İşgali”, (Yayımlanmamış Yüksek Lisans Tezi) Ankara, 2007.

Şam, Emine Altunay, “Mısır'ın 1882'de İngilizler Tarafından İşgali ve Osmanlı Devletinin Takip Ettiği Siyaset”, (Yayımlanmamış Doktora Tezi), Samsun, 2001.

Yiğit, Verda, "1648 Vestefalya Barışından 1815 Viyana Kongresine Kadar ki Dönemde Uluslararası Sistemin Dönüşümü”, (Yayımlanmamış Yüksek Lisans Tezi), İstanbul, 2008. 